\title{
Crystallization of Santeri's Religious Attitudes through the Boarding Cultural Process
}

\author{
Mahlil Nurul Ihsan, Nurwadjah Ahmad, Aan Hasanah, Andewi Suhartini \\ Mahasiswa Pascasarjana UIN Sunan Gunung Djati Bandung, Indonesia \\ Email: mahlilnurulihsan05@gmail.com, nurwadjah.ahmad@uinsgd.ac.id, \\ aan.hasanah@uinsgd.ac.id, andewi.suhartini@uinsgd.ac.id
}

\begin{abstract}
ARTICLE INFO
Received

08 September 2021

Revision

13 September 2021

Approved

17 September 2021

Keywords:

Crystallization of

students' religious

attitudes;

Boarding cultural

process

ABSTRACT

Each Boarding culture has a unique variation in shaping the religious attitudes of students. This problem was initially caused by the weakness of the Boarding culture, which caused the moral decadence of students so that the process of Boarding culture had to be strengthened. This type of research uses qualitative field research with descriptive methods and data collection techniques using interviews, documentation, and observation. This study explains the cultural process of the modern AlAqsho Islamic boarding school, Sumedang Regency, consisting of religious socialization, modernity, moderation, adaptation emphasizing modern life systems, habituation which is applied more to the habituation of the grantor system, and enculturation showing modern Boarding culture. Meanwhile, the cultural process of Al-Ittifaq Islamic Boarding School in Bandung Regency consists of religious socialization, entrepreneurship, and society, adaptation emphasizing the adaptation of spiritual experiences, adaptation highlighting the social life system of the community, adaptation to the entrepreneurial work environment, habituation applied to the religious method, community and entrepreneurship and enculturation shown religious agribusiness Boarding culture.
\end{abstract}

\section{INTRODUCTION}

Boarding is a religious environment with religious values embodied in spiritual experiences that can be actualized by applying Boarding culture. Each Boarding has an essential role in shaping the faith, holiness, and religious attitudes of students that benefit their lives through teaching, habituation, example, training, motivating, and enforcing the rules of the Boarding. These efforts show the form of Boarding's cultural life, which aims to critique the religious attitudes of students. The purpose of Boarding cultural education is to shape the religious attitudes of students through the leadership of the Kiyai and then applied by the students (Chasanah, 2021). The philosophy of the Santeri can also be formed through the obedience of the Santeri towards the Kiai so that compliance becomes the culture of the Boarding (Zaenuddin \& Choiriyah, 2021). The cultural climate of the Boarding has an essential role in shaping the attitudes and personality of the Santeri (Prasetyo, 2021). In addition to the formation of the religious philosophy of students, Islamic boarding schools have an essential role in growing life skills, both in empowering students through student entrepreneurship and other abilities (Anggadwita, Dana, Ramadani, \& Ramadan, 2021). Students' ability is formed to understand religion and the world and be useful in their lives.

Religious attitudes are formed from beliefs and practices of spiritual teachings applied in everyday life that can reflect religious attitudes (Naro, Abubakar, Syatar, Amiruddin, \& Pallawagau, 2021). The religious attitudes of students can be formed from the family environment, school
How To Cite:

E-Issn:

Published By:
Ihsan, M. N., et. al. (2021) Crystallization of Santeri's Religious Attitudes through the Boarding Cultural Process. Journal of Social Science 2(5). https://doi.org/10.46799/jss.v2i5.225 2721-5202

Ridwan Institut 
environment, and community, the environment that causes social interaction so that the formation of religious attitudes cannot be separated from interaction with their environment (Asiah, Harjoni, \& Susanto, 2021). A religious attitude can lead to solid tolerance. Religion has an essential role in forming religious, social, and tolerant attitudes, so that religious attitudes are necessary to be possessed by all humans. The philosophy of tolerance is part of a spiritual attitude. There is patience to face differences in culture, religion, and ideology so that tolerance reflects applying high religious perspectives in social life (Verkuyten, Adelman, \& Yogeeswaran, 2021). Religious attitudes are formed by love for God and others, so growing love for religion is a driving force for someone to take religious actions and attitudes (Guleryuz Erken, Francis, \& McKenna, 2021). Religious attitudes can be formed by inculcating the value of religious moderation through the learning process of cross-cultural understanding courses (Nirwana \& Darmadali, 2021). When religious perspectives have become a religious culture, life will be balanced, moderate, and harmonious (Nisa, 2021).

The previous research related to this research is as follows: the influence of culture-based education on increasing knowledge for people with hypertension that occurs in the Makassar community in Indonesia (Ningsih, Nurdin, Puspitha, Malasari, \& Kadar, 2020), The new learning culture of Boarding in standard times inform the leadership attitude of students in dealing with COVID 19 (Hanafi et al., 2021), the principles of Islamic culture in shaping the quality of life in Islamic cities by identifying the basic Islamic ideology of the Qur'an and the character of the prophet about governance. Life in an Islamic city (Jamalinezhad, Talakesh, \& Soltani, 2012), the impact of religion and culture on health in the Middle East and Europe, because religion and culture have an essential role to play in creating a healthy and socially good life (Serour \& Serour, 2021) , forming environmental social attitudes through environmental culture in Russia with the results of his research that behavioral patterns of s social and individual actions are influenced by the cultural circumstances of their environment (Valko, 2021), the role of board game culture in shaping human attitudes and personality cross-cultural comparative research between Denmark, Germany and the United States results of his research that board game culture can affect the behavior and attitudes of Danish citizens, Germany and America, because board games raise emotions and emotions bring up one's perspectives and personality (Bar \& Otterbring, 2021), building Islamic civilization through the paradigm of Islamic education in the future with the integration of Boarding and favorite Boarding. With quality Islam, the Islamic education system must be reformulated by the dynamics of the times, market needs, to produce quality scholars and scholars who are scientists (Das, W. H., Halik, A., 2016), the application of Islamic entrepreneurship activities in Islamic boarding schools to shape religious attitudes of students (Zaki, Widiastuti, Yudha, Wijayanti, \& Mi'raj, 2020), the organizational culture of Boarding can be formed through the formation of a Salafi culture in Boarding, the maintenance of Salafi culture in modern boarding schools, Boarding culture is initiated because of the existence of an essential book that reflects the values of the Islamic boarding school. Salafi values, the presence of women, band organ, organ methods, a unique curriculum system, and clothes and uniforms that characterize the diversity of students (Musaddad, 2021), character building through language culture and Boarding culture in instilling religious and cultural attitudes in boarding schools (Tharaba, Yaqien, Fattah, Vincent, \& Ariswati, 2021).

Based on the explanations of previous studies, many explain religious culture, Boarding culture, and educational culture. At the same time, this research focuses on the crystallization of religious attitudes of students through the process of Boarding culture so that the study's novelty will be seen because it is different from previous studies. The purpose of this study is to explain the crystallization of the religious attitudes of students through the Boarding cultural process, which includes cultural stages (socialization, adaptation, habituation, and enculturation). 


\section{METODE}

This study uses qualitative research using descriptive field methods. This research was conducted in two Islamic boarding schools, namely the modern Islamic boarding school Al-Aqsho, Sumedang Regency, and the Al-Ittifaq agribusiness boarding school, Bandung Regency, which have different Boarding cultures. The data collection techniques consisted of interviews, observation, and documentation.

\section{RESULTS AND DISCUSSION}

The Boarding culture is part of Boarding education. In its activities, there is a process of civilizing the Santeri to the practice of Islamic teachings so that it is formed into a Boarding culture. The Boarding culture introduced by (Sandy \& Puspitawati, 2019) in his theory explains that the cultural process is initiated due to the stages of the socialization process, the adaptation process, the habituation process, and the enculturation process. This theory is suitable for use in this study to discuss the cultural function of the modern Islamic boarding school Al-Aqsa Kab. Sumedang and Boarding Al-Ittifaq Kab. Bandung so that the novelty and cultural differences of typical Boarding will be seen, which are very important to learn and understand to improve Islamic education science in the world of Islamic boarding schools to apply Islamic theory in forming students' religious attitudes.

The process of Boarding culture in modern Boarding Al-Aqsa Kab. Sumedang and Boarding Al-Ittifaq Bandung Regency proves that these two Boardings have a Boarding cultural revolution that is carried out so that a Boarding culture is formed as a form of education in shaping the religious attitudes of students in Boarding. By examining the process of Boarding culture in the modern Boarding of Al-Aqsa Kab. Sumedang and Boarding Al-Ittifaq Kab. Bandung, we can analyze the stages of the Boarding cultural process in shaping the religious attitudes of the Santeri in the Boarding.

In general, the process of Boarding culture in the modern Boarding of Al-Aqsa Kab. Sumedang and Boarding Al-Ittifaq Kab. Bandung consists of The first stage of socialization. Firstly, the culture of the Boarding is introduced through the introduction of the culture of the Boarding.
The Boarding program (teaching of worship, imitation of religious attitudes, habituation, motivation, and introduction to the Boarding rules) and the Boarding policies in the Boarding. Modern Al-Aqsa Kab. Sumedang and Boarding Al-Ittifaq Kab. Bandung. The second stage is the adaptation of students' adjustment to the Boarding environment, whether it involves the active interaction of students in carrying out the Boarding program. The third stage of habituation of students is carried out gradually and consistently, which is carried out routinely and continuously using daily, weekly, monthly, and yearly student habituation programs. The last stage, namely the enculturation of students, is the previous process of acculturating students so that the Santeri Boarding program becomes a Boarding culture.

While specifically the process of Boarding culture in the modern Boarding of Al-Aqsa Kab. Sumedang and Boarding AlIttifaq Kab. Bandung can be detailed from the table below:

\section{Socialization}

Socialization in the cultural process is the first stage that causes culture to occur. The socialization process occurs in individuals when behavioral patterns, motivational drives, and values are instilled (Grusec \& Hastings, 2014). In the child development theory, socialization occurs because of group interactions that affect the child's lifestyle (Harris, 1995). In the view of socialization, it is formed because of the knowledge, social sensitivity, and culture of the environment interconnected so that socialization occurs (Ochs \& Schieffelin, 2011). Socialization is the fundamental mechanism of social reproduction because socialization has become part of the culture in instilling the values of human life (Guhin, Jeffrey, Calarco, J. M., \& Idriss, 2021). In the world of education, it cannot be separated from culture, so the extensive theory of socialization recognizes that socialization and education are basic expressions in developing human culture (Grundman, 2021).

The socialization in the modern Islamic boarding school Al-Aqsa Sumedang Regency, in the process of Boarding culture being formed, involved 
the socialization of religious teaching, modern Islamic boarding schools, and the enforcement of Boarding rules. Socialization in the contemporary Islamic boarding school Al-Aqsa Kab. Sumedang is characterized by modernity, moderation, coupled with English and Arabic extracurriculars as a reinforcement of academic culture, while the socialization of modern Islamic boarding schools is to create a contemporary culture of Al-Aqsa Kab. Sumedang. The form of socialization of religious teaching is through religious educative lectures, religious knowledge such as Islamic boarding school books, teaching students equipped with spiritual guidance, study guidance, and evening guidance. Then this religious teaching is strengthened by khutbatul arsy, or the introduction of Boarding culture to socialize with the Islamic boarding school environment and boarding school rules. In addition to the socialization of Islamic boarding schools, there is also the socialization of the students' leadership, which aims to train the independence and responsibility of the students in carrying out their duties and obligations as modern Santeri of Al-Aqsho Kab. Sumedang is called OPPM.

While the socialization at the AlIttifaq agribusiness boarding school, Kab. Bandung has the characteristics of Islamic boarding school socialization, entrepreneurship socialization, and socialization. Boarding socialization includes religious socialization of students in carrying out daily worship, studying spiritual knowledge, and carrying out programs related to religion and worship and accompanied by the application of noble character in everyday life of students and carrying out Islamic boarding school rules. Then there is what is called the socialization of entrepreneurship through teaching and fostering student activities in agribusiness, which is the hallmark of the activities of Al-Ittifaq Kab. Bandung, because the socialization of entrepreneurship in this Boarding has an essential role so that students have skills, are helpful for the people and can increase independence and improve the economy as an effort for Boarding to empower students as entrepreneurs. The form of entrepreneurship socialization is related to teaching the management of plants, vegetables, fruits, and livestock as the empowerment of natural resources utilized for their goodness to improve the economy and welfare of the people. The socialization of the community has an essential role so that students can live in society well and provide significant benefits for the people. Forms of community socialization, for example, holding a boarding school cooperative, cooperation between students and the community in entrepreneurial activities, and applying social, a religious society so that the life of the Boarding is very prosperous, harmonious, comfortable, and peaceful.

\section{Adaptation}

Adaptation has an essential role in the cultural process because, with the transformation of humans to their environment, they can maintain survival and maximize good human potential (Pittock \& Jones, 2000). With adaptation, all life is in an excellent orderly system, so that adaptation occurs when there is a balance of energy (Kauffman, 1991). The process of human transformation is always associated with human interaction with the environment so that a sustainable life process will occur (Brandon, 2014). Adaptation theory can explore the development of sustainable creative adaptation so that in its application, transformation is central to human culture (Hutcheon, 2012). Adaptation has an essential role in drawing patterns of human interaction with the environment to realize a picture of human civilization (Sanders, 2015).

The adaptation process in the modern Islamic boarding school Al-Aqsa Sumedang Regency is done through the introduction of Islamic boarding school culture so that with the introduction of Modern Islamic boarding school culture, students can adapt to the Islamic boarding school environment along with the programs and rules that exist in this Santeri adaptation boarding school when students can interact with the leaders of the Islamic boarding school and each other. The adaptation of students at the Modern Al Aqsa Islamic Boarding School in 
Sumedang Regency occurs when the students enter the Boarding early and then adapt every day to the Boarding environment and carry out modern Boarding programs and rules which are also supported by the interaction of fellow Boarding residents, both Boarding leaders, Boarding teachers, and their fellow students. The adaptation of the Modern Al Aqsa Santeri of Sumedang Regency to adopt the Panca soul of the Gontor Islamic Boarding School, which is the soul of the modern Santeri is reflected in the sincerity, simplicity, standing of Islamic brotherhood and discipline so that the spirit of the Santeri soul is applied by carrying out life in the Boarding so that the life of modern Santeri reflects religious values and moderate values and life balance So that Modern Al Aqsa students are not left behind by the times, because students have good adaptations to the development of modern times.

Meanwhile, the adaptation of students at the Al-Ittifaq Islamic Boarding School in Bandung Regency went well because the students were able to adapt to the religious environment of the Islamic boarding school, the community, the natural environment, and the entrepreneurial environment, which caused the Al-Ittifaq students of Bandung Regency to have good religious competence and work competence because all programs Islamic boarding schools and entrepreneurship programs are carried out in a balanced manner. The adaptation of Al ittifaq students in Bandung district reflects religious values and also practices the importance of a good work ethic and natural empowerment, which is carried out and utilized optimally so that this Islamic boarding school grows with goodness and blessings so that it becomes an advanced Islamic boarding school in the field of religion and Islamic economics. The adaptation of students at Al ittifaq Islamic boarding school in Bandung district has a balance in adapting to the religious environment and the community environment as well as the surrounding natural environment whose interactions are carried out in a stable and dynamic harmony so that this boarding school is famous for its religious, cultural values and work culture.

\section{Habituation}

The theory of habituation occurs because of the process of response plasticity that arises repeatedly. Habituation impacts the formation of human attitudes in the process of social culture (Groves \& Thompson, 1970). The habituation process can be formed by fear that drives a person to learn and do, anxiety when not doing, and repetition to become accustomed to doing something (Benito \& Walther, 2015). The habituation process must be based on the child's awareness to develop proper habituation attitudes (Hartkopf, Moser, Schleger, Preissl, \& Keune, 2019). Habituation is formed due to a program system that regulates children's lives. If habituation contains education, the rules applied are educational rules (Rachmayani, Karta, Astawa, \& Nurhasanah, 2021). School or Islamic boarding programs can affect children's habituation patterns (Imtihanudin \& Mariana, 2021). Educational culture requires positive habits to form good student attitudes and character (Nurafiati, Rahayu, \& Sugiharto, 2021). Designing an excellent academic culture requires a continuous habituation process so that children form better attitudes and personalities by including extra-curricular programs (Muthohar, 2021).

The habituation process at the modern Islamic boarding school Al-Aqsho, Sumedang Regency applies a process of habituation of worship, habituation to running a current Boarding program and getting used to carrying out modern boarding school rules that the habituation of students is carried out correctly. The habituation of students at the modern Islamic boarding school, Al-Aqsho Sumedang Regency, consists of daily, weekly, monthly, and yearly habits that are applied, namely habituation of worship, habituation of academic language, habituation of obedience to boarding school rules and regulations. The habituation of modern Santeri at Al-Aqsho in Sumedang Regency emphasizes the religious attitude of moderate, open, and tolerant students. The habituation of these 
students is strengthened by the motto of the Boarding standing above all groups. The habituation of students is formed through modern Santeri organizations as a complement and reinforcement of the religious attitude of students.

The habituation process at the AlIttifaq agribusiness boarding school in Bandung Regency involves the habituation of students in worship, socializing with the community, and habituation in the entrepreneurial work ethic of students in boarding schools. The habituation of students involves the habituation of daily, weekly, monthly, and yearly routines. The habituation of Al-Ittifaq students in Bandung Regency is supported by a harmonious social environment and a healthy natural environment so that religious attitudes are well-formed and supported by a prosperous life. The habituation process at Al-Ittifaq Islamic Boarding School in Bandung Regency is well controlled because it is supported by Boarding wise arrangements and wellorganized management of Boarding.

\section{Enculturation}

Enculturation has an essential role in inheriting and maintaining culture so that with the enculturation process, civilization will continue to live (Raharjo, Soesanto, Rohidi, \& Utomo, 2021). Enculturation is a vehicle for culture and knowledge that impacts human development (Pulatova, 2021). Educational values can be realized through cultural enculturation that is applied continuously to apply these values in students' lives. Enculturation is used as a means of civilizing education in shaping student attitudes (Aisyah, 2021). In the process of enculturation, it can cause patterns of human culture that occur because of roles, values, norms, and cultures that correlate with one another. They adjust their attitudes and thoughts to the customs, system of models, and regulations that apply in their cultural life. The process of enculturation is complex throughout human life, but the process varies depending on the life stages of individuals and groups. All human life, whether it's family, school, and society, is a conscious or unconscious enculturation process because the enculturation process has started since childhood, first in the family environment, then playing friends, going to school to community so that the enculturation process is an aspect of human life whose process is human life.

The process of enculturation in the modern Boarding of Al-Aqsho, Sumedang Regency is going well because socialization, adaptation, and habituation are carried out continuously so that a modern Boarding culture is formed characterized by moderate, balanced, and dynamic religion. The process of enculturating the culture of the current Islamic boarding school Al-Aqsho, Sumedang Regency, has become a form of modern culture in which there is a culture of independence, a culture of discipline, a culture of worship, academic culture, a culture of tolerance, a culture of mutual assistance, a clean culture of Boarding and many other cultures formed. Through the process of enculturation to crystallize the moderate religious attitudes of modern Santeri.

The enculturation process at the AlIttifaq agribusiness boarding school in Bandung Regency is well and harmoniously interwoven because the enculturation process occurs because of the interaction of the Boarding culture, the social culture of the community, the agribusiness culture that runs side by side and complements each other and strengthens the formation of the religious attitude of students who are productive, creative, intelligent, social and skilled in the world of entrepreneurship. The process of enculturation of the Al-Ittifaq agribusiness boarding school in Bandung Regency. The method of enculturation of the Al-Ittifaq agribusiness boarding school in Bandung Regency displays a culture of devout worship, community social culture, entrepreneurial work culture, culture, the culture of mutual assistance, culture of discipline, culture of independence, culture of simplicity, the culture of Islamic unity, and thriving economic culture. More clearly can be seen in Table 1 below: 
Tabel 1

\begin{tabular}{|c|c|c|}
\hline No & $\begin{array}{l}\text { Name of } \\
\text { Islamic } \\
\text { Boarding School }\end{array}$ & Islamic Boarding School Cultural Process \\
\hline 1 & $\begin{array}{lr}\text { Modern } & \text { Islamic } \\
\text { Boarding } & \text { School } \\
\text { Al-Aqsa } & \text { Kab. } \\
\text { Sumedang } & \end{array}$ & $\begin{array}{l}\text { 1. Socialization includes: socialization of worship, socialization of } \\
\text { modern Islamic boarding schools, socialization of khubtatul arsy } \\
\text { (introduction to Islamic boarding school culture), and } \\
\text { socialization of boarding school rules } \\
\text { 2. Adaptation. The adaptation of the Boarding occurs after the } \\
\text { Santeri are given an introduction to the boarding culture so that } \\
\text { the Santeri can adapt to the Boarding environment, both } \\
\text { programs, and the rules of the board. } \\
\text { 3. Habituation includes habituation of students of Al-Aqsa Kab. } \\
\text { Bandung began to be formed from daily, weekly, monthly, and } \\
\text { yearly habituation programs that were carried out regularly and } \\
\text { continuously so that the habituation of students in Boarding was } \\
\text { firmly attached to students' attitudes. } \\
\text { 4. The process of civilizing Boarding runs synergistically when } \\
\text { socialization, adaptation, and habituation of Boarding are carried } \\
\text { out in a balanced manner so that it becomes a Boarding culture } \\
\text { with a modern system. The Boarding culture that is formed is the } \\
\text { culture of Santeri discipline, the culture of the Koran, the culture } \\
\text { of language, the culture of independence of the students, the } \\
\text { culture of the leadership of the students, the culture of the } \\
\text { simplicity of the students, the culture of cleanliness of the } \\
\text { students, the culture of obedience of the students, the culture of } \\
\text { the discipline of the Boarding. }\end{array}$ \\
\hline
\end{tabular}

2 Al-Ittifaq

Agribusiness

Islamic Boarding

School Kab.

Bandung

1. Socialization includes Islamic boarding school socialization, socialization, and socialization of entrepreneurship.

2. Adaptation includes an adaptation of the Boarding environment, social transformation of the community, and adaptation of the natural environment through entrepreneurship.

3. Habituation. The process of habituation of students at the AlIttifaq Islamic Boarding School includes the habituation of daily, weekly, monthly and yearly worship, but what is a plus for this Boarding is the existence of social and entrepreneurship programs as programs to strengthen the religious attitudes of students so that students have a balance of spiritual knowledge, worship, noble character, and job skills.

4. The process of enculturating the students of Al-Ittifaq is carried out in stages, balanced and consistent in cultivating the culture of the Boarding so that a culture of independence of students is formed, the culture of reciting, the culture of discipline in the worship of students, the culture of work and entrepreneurship for students, the culture of helping the social community of the Boarding, the culture of cleanliness Boarding environment, society and nature. The culture of this Boarding uses the Salafi system, organization, and agribusiness.

Boarding Al-Ittifaq Kab. Bandung has the

Based on the explanation of the table above, it can be concluded that the boarding culture process occurs in modern Boarding Al-Aqsho Kab. Sumedang and same stages of cultural processes involving socialization, adaptation, habituation, and incursion processes, but the two boardings have different boarding 
culture system approaches and supporting environments. The method of approaching modern boarding culture Al-Aqsho Sumedang Regency uses a modern culture approach that aims to form a religious and moderate Santeri attitude and is supported through the order of the contemporary boarding environment. While the process of cultural

practice Boarding Al-Ittifaq Kab. Bandung uses an entrepreneurial agribusiness approach supported by the social environment of the community and the natural environment that supports the formation of religious, social attitudes and is skilled in entrepreneurship and able to utilize the potential of nature as a value of economic development Santeri and society.

\section{CONCLUSION}

The process of crystallization of Santeri's religious attitudes through boarding culture in modern boarding Al-Aqsho Kab. Sumedang consists of boarding socialization, boarding rules and noble character, adaptation is carried out gradually and consistently in the modern boarding culture and salafi culture, the Santeri habituation process includes daily, weekly, monthly and yearly habituation, and the enculturation process involves modern culture and culture. salafi. While the process of forming the religious attitude of Santeri AlIttifaq consists of the Boarding, social and entrepreneurial socialization process, the adaptation process involves the Boarding cultural environment, community social culture and agribusiness culture), the habituation process involves daily, weekly, monthly and yearly habituation and the enculutation process involves salafi, modern, social culture (help culture) and entrepreneurship (work culture).

\section{REFERENCES}

Aisyah, Nur. (2021). Konsep Pendidikan Islam Menurut Al-Ghazali (Sebuah Analisis Terhadap Kurikulum Pai). Hikmah: Jurnal Pendidikan Islam, 10(1), 7690.Google Scholar

Anggadwita, Grisna, Dana, Leo Paul, Ramadani, Veland, \& Ramadan, Reza
Yanuar. (2021). Empowering Islamic Boarding Schools By Applying The Humane Entrepreneurship Approach: The Case Of Indonesia. International Journal Of Entrepreneurial Behavior \& Research. Google Scholar

Asiah, Nur, Harjoni, Harjoni, \& Susanto, Is. (2021). Inter-Environmental Collaboration To Form Students' Attitudes Toward Diversity. Tadris: Jurnal Keguruan Dan IImu Tarbiyah, 6(1), 29-40. Google Scholar

Bar, Amit, \& Otterbring, Tobias. (2021). The Role Of Culture And Personality Traits In Board Game Habits And Attitudes: Cross-Cultural Comparison Between Denmark, Germany, And The Usa. Journal Of Retailing And Consumer Services, 61, 102506. Google Scholar

Benito, Kristen G., \& Walther, Michael. (2015). Therapeutic Process During Exposure: Habituation Model. Journal Of Obsessive-Compulsive And Related Disorders, 6, 147-157. Google Scholar

Brandon, Robert N. (2014). Adaptation And Environment. Princeton University Press. Google Scholar

Chasanah, Nur. (2021). The Leadership Of Kiai And Students' Obedience In Islamic Boarding School. Resolusi: Jurnal Sosial Politik, 4(1), 42-52. Google Scholar

Das, W. H., Halik, A., \&. Amaludin. (2016). The Role Of Culture And Personality Traits In Board Game Habits And Attitudes: Cross-Cultural Comparison Between Denmark, Germany, And The Usa. 8(4), 24-32. Google Scholar

Groves, Philip M., \& Thompson, Richard F. (1970). Habituation: A Dual-Process Theory. Psychological Review, 775), 419. Google Scholar

Grundman, M. (2021). Education And Socialization." Soziologie-Sociology In The German-Speaking World. Boston. Cpi Books. Google Scholar

Grusec, Joan E., \& Hastings, Paul David. 
(2014). Handbook of Socialization: Theory And Research. Guilford Publications. Google Scholar

Guhin, Jeffrey, Calarco, J. M., \& Idriss, C. M. (2021). The Handbook Of Language Socialization. 47. Google Scholar

Guleryuz Erken, Humeyra, Francis, Leslie J., \& Mckenna, Ursula. (2021). Love For Allah And Love For Others: Exploring The Connection Between Religious Effect And Empathy Among Muslim Adolescents In England. Journal of Beliefs \& Values, 42(2), 223-234. Google Scholar

Hanafi, Yusuf, Taufiq, Ahmad, Saefi, Muhammad, Ikhsan, M. Alifudin, Diyana, Tsania Nur, Thoriquttyas, Titis, \& Anam, Faris Khoirul. (2021). The New Identity Of Indonesian Islamic Boarding Schools In The "New Normal": The Education Leadership Response To Covid-19. Heliyon, 73), E06549. Google Scholar

Harris, Judith Rich. (1995). Where Is The Child's Environment? A Group Socialization Theory Of Development. Psychological Review, 102(3), 458. Google Scholar

Hartkopf, Julia, Moser, Julia, Schleger, Franziska, Preissl, Hubert, \& Keune, Jana. (2019). Changes In Event-Related Brain Responses And Habituation During Child Development-A Systematic Literature Review. Clinical Neurophysiology, 130(12), 2238-2254. Google Scholar

Hutcheon, Linda. (2012). A Theory Of Adaptation. Routledge. Google Scholar

Imtihanudin, Dede, \& Mariana, Ria. (2021). Students'attitude In Learning Islamic Education Courses Through Values Character Habituation. Cakrawala Pedagogik, 5(1), 16-27. Google Scholar

Jamalinezhad, Mahdi, Talakesh, Seyed Mohammadreza, \& Soltani, Seyed Hassan Khalifeh. (2012). Islamic Principles And Culture Are Applied To Improve Life Quality In Islamic Cities.
Procedia-Social And Behavioral Sciences, 35, 330-334. Google Scholar

Kauffman, Stuart A. (1991). Antichaos And Adaptation. Scientific American, 265(2), 78-85. Google Scholar

Musaddad, Ahmad. (2021). Organizational Culture In The Islamic Boarding School: Phenomenology Review. Al-Tanzim: Jurnal Manajemen Pendidikan Islam, 5(1), 154-164. Google Scholar

Muthohar, Ahmad. (2021). Implementation And Development Models Of Character Education In School. Tarbiyah Wa Ta'lim: Jurnal Penelitian Pendidikan Dan Pembelajaran, 69-82. Google Scholar

Naro, Wahyuddin, Abubakar, Achmad, Syatar, Abdul, Amiruddin, Muhammad Majdy, \& Pallawagau, Baso. (2021). Have Attitudes Towards Religiousness Shifted Due Covid 19 Outbreak? Evidence From Moslem Generations In MakassarIndonesia. Palarch's Journal Of Archaeology Of Egypt/Egyptology, 18(3), 322-334. Google Scholar

Ningsih, Andi Pramesti, Nurdin, Nurhaya, Puspitha, Arnis, Malasari, Silvia, \& Kadar, Kusrini. (2020). The Effect Of Culture-Based Education In Improving Knowledge Of Hypertension Patients In Makassarese Community In Indonesia. Enfermeria Clinica, 30, 55-59. Google Scholar

Nirwana, \& Darmadali, W. S. (2021). Menanamkan Nilai Moderasi Beragama Dalam Elt Melalui Kursus Pemahaman Lintas Budaya. Jurnal Studi Bahasa Inggris, 3(2), 117-125. Google Scholar

Nisa, C. (2021). Manajemen Budaya Toleransi Umat Beragama Dalam Pembelajaran Pendidikan Islam Berbasis Multikultural Di Sekolah Negeri. Jurnal Pendidikan Islam, 6(1), 30-45. Google Scholar

Nurafiati, Suastika, Rahayu, Tandiyo, \& Sugiharto, Harry Pramono. (2021). Strategy For Strengthening Character Education In Physical Education Learning At Makassar City Elementary 
Education Level. Journal Of Hunan University Natural Sciences, 48(6). Google Scholar

Ochs, Elinor, \& Schieffelin, Bambi B. (2011). The Theory Of Language Socialization. The Handbook Of Language Socialization, 71(1), 1-11. Google Scholar

Pittock, A. Barrie, \& Jones, Roger N. (2000). Adaptation To What And Why? Environmental Monitoring And Assessment, 61(1), 9-35. Google Scholar

Prasetyo, Muhammad Anggung Manumanoso. (2021). The Effects Of Organizational Climate And Transformative Leadership On Islamic Boarding School Teacher Performance. Jmksp (Jurnal Manajemen, Kepemimpinan, Dan Supervisi Pendidikan), 6(2), 214-235. Google Scholar

Pulatova, Umida F. (2021). Innovative Technologies In Teaching Students Written Translation. Eastern European Scientific Journal, (2). Google Scholar

Rachmayani, Ika, Karta, I. Wayan, Astawa, I. Made Suwasa, \& Nurhasanah, N. (2021). The Development Of The Habituation Sop In Building Early Childhoods' Character By Students' Early Childhood Education Study Program. 2nd Annual Conference On Education And Social Science (Access 2020), 3638. Atlantis Press. Google Scholar

Raharjo, Eko, Soesanto, Soesanto, Rohidi, Tjetjep Rohendi, \& Utomo, Udi. (2021). Preserving Gambang Semarang Music Through The Process Of Enculturation In The Society. Harmonia: Journal of Arts Research And Education, 21(1), 60-67. Google Scholar

Sanders, Julie. (2015). Adaptation And Appropriation. Routledge. Google Scholar

Sandy, Novalita, \& Puspitawati, Puspitawati. (2019). Stereotip Melayu Malas Dan Pengaruhnya Pada Etos Kerja. Journal
Of Education, Humaniora And Social Sciences (Jehss), 2(1), 163-173. Google Scholar

Serour, Gamal I., \& Serour, Ahmed G. (2021). The Impact Of Religion And Culture On Medically Assisted Reproduction In The Middle East And Europe. Reproductive Biomedicine Online. Google Scholar

Tharaba, M. Fahim, Yaqien, Nurul, Fattah, Abdul, Vincent, Shyamala Susan, \& Ariswati, Yuvita. (2021). Character Building Through Language Learning And Culture Of Islamic Boarding Schools In Terms Of Implementing Management Towards Sustainable Development Of The Green Campus. Jilin Daxue Xuebao (Gongxueban)/Journal Of Jilin University (Engineering And Technology Edition), 40, 1-20. Google Scholar

Valko, Danila. (2021). Environmental Attitudes And Contextual Stimuli In Emerging Environmental Culture: An Empirical Study From Russia. Sustainable Production And Consumption, 27, 2075-2089. Google Scholar

Verkuyten, Maykel, Adelman, Levi, \& Yogeeswaran, Kumar. (2021). Tolerance As Forbearance: Overcoming Intuitive Versus Deliberative Objections To Cultural, Religious, And Ideological Differences. Psychological Review. Google Scholar

Zaenuddin, Muhamad, \& Choiriyah, Siti. (2021). Exploring The Cultural Values Of Salaf Islamic Boarding School At Kediri Indonesia. European Journal of Molecular \& Clinical Medicine, 77), 6502-6513. Google Scholar

Zaki, Irham, Widiastuti, Tika, Yudha, Atrc, Wijayanti, Ida, \& Mi'raj, Denizar Abdurrahman. (2020). Implementation Of Islamic Entrepreneurial Culture In Islamic Boarding Schools. International Journal Of Innovation, Creativity, And Change, 11(11), 452-469. Google Scholar 


\section{Copyright holder :}

Mahlil Nurul Ihsan, Nurwadjah Ahmad, Aaan Hasanah, Andewi Suhartini (2021)

First publication right :

Journal of Social Science

This article is licensed under:

(c) (7) (?) 